\title{
Cjeloživotno učenje mladih u kontekstu javnih politika - europska perspektiva
}

\author{
DEJANA BOUILLET \\ VLATKA DOMOVIĆ \\ MONIKA PAŽUR
}

Učiteljski fakultet Sveučilišta u Zagrebu

\author{
Pregledni rad \\ UDK: 373.2(4-11) \\ doi: $10.3935 /$ rsp.v27i1.1635 \\ Primljeno: ožujak 2019. \\ Zagreb, Hrvatska
}

\begin{abstract}
U radu se analiziraju 134 javne politike cjeloživotnog učenja $(C U)$ u devet zemalja uključenih u projekt 'Javne politike koje podržavaju mlade u njihovom životnom putu - Komparativna analiza cjeloživotnog učenja i uključivanja u obrazovanje i rad u Europi' (YOUNG_ADULLLT) koji je razvijen u okviru EU okvirnog programa za istraživanje $i$ inovacije HORIZON 2020. Analiza javnih politika cjeloživotnog učenja se temelji na tri teorijska koncepta - kulturna politička ekonomija, teorija životnog puta i upravljanje. Ciljevi analize se odnose na utvrđivanje procedura formuliranja i implementacije politika $C U$ u pojedinim državama, analizu njihovih specifičnih ciljeva $i$ stupanj koordinacije obrazovnih politika, politika socijalne zaštite i tržišta rada. Analiza pokazuje razlike među zemljama s obzirom na navedene ciljeve koje su posljedica različitih društvenih i ekonomskih okolnosti. Procedure formuliranja politika kreću se od centraliziranih do decentraliziranih. Ciljevi javnih politika cjeloživotnog učenja su trostruki - obrazovni, ekonomski i socijalni, pri čemu njihova zastupljenost varira od zemlje do zemlje. Razine i mehanizmi koordinacije cjeloživotnog učenja također nisu istovjetni te su prepoznate razlike među zemljama s obzirom na centralno upravljani lokalizam, laissez faire $i$ demokratski lokalizam.
\end{abstract}

Ključne riječi: javne politike, cjeloživotno učenje, mladi, Europa.

\section{UVOD}

Termin »javna politika« (eng. policy) odnosi se na namjerno djelovanje institucija vlasti, odnosno na sve što relevantni politički akteri u nekom društvu odluče učiniti ili ne učiniti s dugoročnom namjerom rješavanja ekonomskih, socijalnih, demografskih ili ostalih problema u nekoj političkoj zajednici (Petek, 2012.; Miošić, Berković i Horvat, 2014.; Petek, 2016.; Širinić, 2016.).
Colebatch i Hoppe (2018.) kao zajednička obilježja javnih politika izdvajaju djelatnost vlade, odgovor na probleme, formalno oblikovanje u vidu dokumenata, temeljenost na relevantnim informacijama i usmjerenost oblikovanju praktičnog djelovanja. Tri su temeljna kriterija koja određuju javnu politiku (Burstein, 1991., prema Petek, 2012.):

- sadržajni: dijele inherentan sadržaj i logiku koja ih čini smislenom cjelinom

* Dejana Bouillet, Učiteljski fakultet Sveučilišta u Zagrebu / Faculty of Teacher Education, University of Zagreb, Savska cesta 77, 10000 Zagreb, Hrvatska / Croatia, dejana.bouillet@ufzg.unizg.hr 
- organizacijski: stvara se na temelju dijeljenog interesa više aktera za istu grupu problema koji se međusobno prepoznaju u zajedničkom podsustavu

- kulturološki - zajedničko razumijevanje o tome što jest, a što nije društveni problem, odnosno kako društvo funkcionira ili kako bi trebalo funkcionirati.

Prema sudionicima je javne politike moguće podijeliti na horizontalnu (vodoravnu), vertikalnu (okomitu) i društveno-konstruktivističku dimenziju (Colebatch, 2006.). Dok se okomita dimenzija odnosi na javne sektore, odnosno vladine resore koji imaju moć odlučivanja, »vodoravna dimenzija određuje javne politike kao ishode strukturirane interakcije aktera koja nastaje oko rješavanja kolektivnih problema « (Petek, 2016.: 9), a obuhvaća civilno društvo, tržište, obrazovne ustanove i druge aktere. Društveno-konstruktivistička dimenzija odnosi se na društveni konstrukt problema, odnosno »ideje koje određuju da je neko društveno stanje kolektivni problem« (Petek, 2016.: 10), pa je svaka politika vrijednosno određena.

Javne politike provode se posredstvom različitih instrumenata, odnosno oblicima djelovanja koje Hill (2005.) sistematizira u četiri osnovne skupine (financije, pravne ovlasti, organizacija i informacije). Unutar svake skupine postoje sadržajni (npr. zakonski i podzakonski propisi) i procesni (sustav donošenja odluka) instrumenti kojima se nastoji djelovati na javne probleme i područja. Međutim, javne politike se u pravilu razvijaju kroz političke procese koji mogu uključivati političke konflikte, borbu za moć, političke taktike i strategije s obzirom na različite interese političkih aktera (Kotthof i sur., 2017.) pa su često kontroverzne (Colebath i Hoppe, 2018.). Budući da su javne politike »stalan proces društvenog djelovanja i interakcije « (Colebatch, 2006: 16), mnogo je razlika u načinima na koje se one prakticiraju u različitim zemljama i u različitim resorima. To je u skladu s činjenicom da su javne politike rezultat specifičnih značajki neke zemlje, odnosno interakcije njenog političkog sustava s njenim drugim sustavima, kao što su, na primjer, kulturni i ekonomski (Mataković i Cajner Mraović, 2014.). Uz to, javne politike odvijaju se na različitim razinama - lokalnoj, regionalnoj i nacionalnoj, a u slučaju Europske unije, i na multinacionalnoj razini. Upravo su javne politike namijenjene mladima već desetljećima u fokusu političkog interesa europskih institucija. Tako Europska komisija, Vijeće Europe i druge institucije formuliraju smjernice, a nacionalne ih vlade operacionaliziraju u vlastitim politikama za mlade. Budući da su mnogi aspekti politika za mlade u nadležnosti država članica (npr. obrazovanje, socijalna zaštita zapošljavanje), zajednički ciljevi nastoje se usuglasiti otvorenom metodom koordinacije ${ }^{1}$. Premda ima neobavezujući karakter, ova metoda otvara prostor međunarodnih institucija da indirektno pridonose ujednačenosti javnih politika koje uključuju najmanje tri razine vlasti (europsku, nacionalnu i regionalnu, odnosno lokalnu). Radi se o konceptu višerazinskog upravljanja (eng. multilevel governance) koji se temelji na pregovorima i usuglašavanju interesa raznih dionika (Pierre i Peters, 2005.).

U ovom je radu pozornost usmjerena jednom segmentu nacionalnih javnih politika, u svrhu analize načina na koje se cjeloživotno učenje mladih operacionalizira u javnim politikama europskih zemalja. $\mathrm{U}$ radu je prikazan dio rezultata međunarodnog projekta »Javne politike koje podržavaju mlade u njihovom životnom putu Komparativna analiza cjeloživotnog učenja

\footnotetext{
${ }^{1}$ Metoda otvorene koordinacije je dodatno potaknuta Lisabonskom strategijom 2000. godine. Pri tom je Europska komisija akter koji potiče mreže stručnjaka i različite epistemičke zajednice te organizacije civilnog društva na razvoj politika u nizu sektora, a uloga Europske unije ogleda se u monitoringu, evaluaciji i policy transferima (Babić Krešić, 2014.).
} 
i uključivanja u obrazovanje i rad u Europi« (YOUNG_ADULLLT) koji je razvijen u okviru EU okvirnog programa za istraživanje i inovacije HORIZON 2020. Projekt je od 2016. do 2019. godine realiziran u 9 europskih država, uz sudjelovanje znanstvenika sa 14 sveučilišta ${ }^{2}$. U sklopu projekta provedeno je kvalitativno (analiza dokumentacije, intervjui s mladima i dionicima javnih politika) i kvantitativno (statistički podaci) istraživanje koje je usmjereno ostvarivanju tri osnovna cilja:

- analiza različitih modela i ciljeva politika cjeloživotnog učenja u Europi

- utvrđivanje očekivanih i neočekivanih utjecaja politika cjeloživotnog učenja na mlade

- definiranje preduvjeta koordiniranih politika cjeloživotnog učenja na regionalnim i lokalnim razinama.

\section{PRISTUPI CJELOŽIVOTNOM UČENJU U JAVNIM POLITIKAMA}

Iako je na pozicioniranje cjeloživotnog učenja (eng. life-long learning) kao važnog javno-političkog problema uvelike utjecala organizacija Ujedinjenih naroda za obrazovanje, znanost i kulturu (UNESCO ${ }^{3}$ ), na međunarodnoj i na nacionalnim razinama cjeloživotno učenje dobiva sve veću pozornost i smatra se ključnim konceptom u promociji brojnih društvenih i gospodarskih ciljeva, kao što su unaprjeđenje djelotvornosti i učinkovitosti obrazovanja, usklađivanje (potreba) sustava obrazovanja i tržišta rada, ublažavanje učinaka preranog napu- štanja formalnog obrazovanja te povećanje stupnja socijalne ravnopravnosti (Vourien i Watts, 2013.). Unatoč nastojanjima protagonista neoliberalne ideologije da cjeloživotno učenje bude usmjereno prema postizanju ekonomskih i gospodarskih ciljeva nacionalnih i međunarodnih politika, UNESCO kontinuirano zagovara socijalno-demokratski liberalni pristup cjeloživotnom učenju, određujući ga kao kolektivnu vrijednost koja se ne može prepustiti tržištu, već zahtijeva snažnu involviranost država i njezinih poluga vlasti (Lee i Friedrich, 2011.). Drugim riječima, cjeloživotno učenje jedno je od područja javnih politika u kojemu je potreban balans odgovornosti između države, regionalnih i lokalnih vlasti, odgojno-obrazovnog sustava i tržišta rada, nevladinog sektora, te javnih i privatnih institucija.

Ipak, koncept cjeloživotnog učenja zadrŽao je dualističku prirodu razvijenu tijekom 1990-ih godina 20. stoljeća. S jedne strane, postoji »utopijska vizija« obrazovanja kao mehanizma koji omogućava socijalnu jednakost (Volles, 2016.), a s druge strane, obrazovanju se pristupa kao ključnom čimbeniku koji povećava zapošljivost mladih (Katzenlson, 2016.). Uz to, postoje autori koji propituju doprinos obrazovanja društvenom napretku i ostvarenju autonomije pojedinca (Hake, 1999.). Nedvojbeno je da cjeloživotno učenje predstavlja osnovu osobnog razvoja svakog pojedinca jer podrazumijeva sve odgojno-obrazovne aktivnosti tijekom života koje rezultiraju stjecanjem znanja, razvojem vještina i kompetencija i/ili kvalifikacija koje služe osobnom, socijalnom i /ili profesionalnom razvoju

\footnotetext{
${ }^{2}$ Koordinator projekta je Sveučilište u Münsteru (Njemačka), a uz Učiteljski fakultet Sveučilišta u Zagrebu, u njemu su sudjelovali i Sveučilište obrazovanja Freiburg (Njemačka), Sveučilište u Frankfurtu (Njemačka), Sveučilište u Plovdivu (Bugarska), Južno-zapadno sveučilište u Blagovgradu (Bugarska), Sveučilište u Glasgowu (Ujedinjeno Kraljevstvo), Sveučilište u Lisabonu (Portugal), Sveučilište u Portu (Portugal), Samostalno sveučilište u Barceloni (Španjolska), Sveučilište u Granadi (Španjolska), Sveučilište u Genovi (Italija), Sveučilište u Beču (Austrija) i Sveučilište u Turku (Finska).

${ }^{3}$ UNESCO je ideju cjeloživotnog učenja, nazivajući ga cjeloživotnim ili trajnim obrazovanjem, razvio prvi, 60-ih godina 20. stoljeća. Nakon Faureovog izvješća iz 1972. godine, Delors u svom izvještaju iz 1996. godine cjeloživotno učenje definira kao ključ bolje budućnosti (Duke i Hinzen, 2011.).
} 
(CEDEFOP, 2014.). Obuhvaća sveukupno opće obrazovanje, strukovno obrazovanje i osposobljavanje, neformalno obrazovanje i informalno učenje koje se provodi tijekom cijelog života, a rezultira poboljšanjem znanja, vještina i kompetencija unutar osobne, građanske, društvene i/ili perspektive vezane uz zapošljavanje (European Parliament and the Council of Europe, 2006., čl. 2). Memorandum o cjeloživotnom učenju (2000.) Europske komisije unaprjeđivanje cjeloživotnog učenja smatra nužnim za uspješnu tranziciju prema društvu i ekonomiji utemeljenim na znanju pa europski sustavi obrazovanja i osposobljavanja predstavljaju bit nadolazećih promjena, a zapošljivost i aktivno građanstvo najvažniji su ishodi procesa cjeloživotnog učenja.

S vremenom se cjeloživotno učenje od početne ideje razvilo u dominantno načelo i orijentaciju razvoja brojnih nacionalnih obrazovnih sustava, uključujući i hrvatski obrazovni sustav. Strategija obrazovanja, znanosti i tehnologije (2014.) svrhu cjeloživotnog učenja vidi u ostvarivanju i razvoju osobnih potencijala i aktivnom građanstvu te omogućavanju bolje zapošljivosti pojedinca, odnosno povećanja njegove konkurentnosti na tržištu rada. U dokumentu se također naglašava da upravo obrazovanje odraslih može utjecati na tijek gospodarske krize. »Tržište rada«, »zapošljivost«, »fleksibilnost « $\mathrm{i} »$ mobilnost« ključne su teme cjeloživotnog učenja na razini Europske unije (Volles, 2016.). Primjerice, cilj Strateškog okvira za europsku suradnju u području obrazovanja i osposobljavanja (ET2020) iz 2015. godine jest potaknuti zemlje članice na poduzimanje mjera koje će osigurati da mladi ljudi razviju vještine i kompetencije potrebne tržištu rada s naglaskom na poduzetničke i druge transverzalne vještine.

Nesporno je kako se suvremeno društvo ubrzano mijenja zbog čega postaje rizično mjesto odrastanja s promijenjenim obrasci- ma konstrukcije mladosti kao životne etape prijelaza u odraslost. Među autorima postoji određeni stupanj suglasnosti u Europi da problemi na koje nastoje odgovoriti programi cjeloživotnog učenja (nezaposlenost, ponovno uključivanje u obrazovanje, rizik od socijalne isključenosti) posebno pogađaju skupinu mladih (Ilišin i Spajić-Vrkaš, 2017.). Stoga se na obrazovanje često gleda kao na instrument koji može odgovoriti na određene probleme mladih, kao što su osobni i obiteljski problemi, bolje pozicioniranje na tržištu rada i ostvarenje kontakta s realnim gospodarstvom (Rambla i sur., 2018.). U idealnom slučaju, cjeloživotno učenje je »alat « za sinkronizaciju profesionalnih i obrazovnih aspiracija mladih s promjenjivim potrebama tržišta rada. Na tom je tragu i europska »Garancija za mlade $\ll^{4}$ (2013.) koja definira mjere za olakšavanje prijelaza mladima iz sustava obrazovanja u svijet rada, među kojima važna uloga pripada kvalitetnom profesionalnom usmjeravanju mladih, cjeloživotnom učenju te poticanju zadržavanja mladih u sustavu obrazovanja.

U europskim zemljama se u odnosu na cjeloživotno učenje uočavaju napetosti i teškoće jer se obrazovnim reformama nastoji istodobno postići gospodarska konkurentnost uz održavanje socijalne kohezije društva temeljenog na znanju (Žiljak, 2005.).

Usmjeravajući se na regionalne/lokalne kontekste politika cjeloživotnog učenja u 9 europskih država, projekt YOUNG_ADULLLT istražuje i analizira interakciju i komplementarnost politika cjeloživotnog učenja nastalih u različitim sektorima, s ciljem boljeg razumijevanja njihovoga odnosa i omogućavanja definiranja parametara za donošenje odluka o budućim sustavima potpore mladima. U ovom je radu predstavljen dio rezultata kvalitativnog istraživanja, s ciljem utvrđivanja načina na koje je cjeloživotno učenje operacionalizirano i implementirano u javnim politikama u sustavima obrazova-

${ }^{4}$ https:/eur-lex .europa.eu/LexUriServ/LexUriServ.do?uri=OJ:C:2013:120:0001:0006:EN:PDF 
nja, zapošljavanja i socijalne zaštite mladih. Cilj je operacionaliziran usmjeravanjem pozornosti na sljedeća istraživačka pitanja:

1. Koji su prevladavajući mehanizmi donošenja i implementacije javnih politika koje pridonose cjeloživotnom učenju u europskim državama?

2. Kako se dominantni ciljevi javnih politika odražavaju na cjeloživotno učenje mladih?

3. Jesu li politike iz sustava obrazovanja, socijalne zaštite i tržišta rada međusobno kompatibilne i koordinirane?

\section{POLAZIŠTA ANALIZE}

U projektu YOUNG_ADULLLT javne politike definirane su u širem smislu. One uključuju različite oblike politika koje se kreću u rasponu od niske razine konkretnosti do vrlo konkretnih mjera, projekata i/ ili programa. Obuhvaćaju politike koje su formalno inicirane i vođene od strane jedne ili većeg broja institucija (npr. ministarstva gospodarstva ili ministarstva obrazovanja), ali i one politike koje iniciraju i provode različite mreže (npr. nevladine organizacije). Na temelju tako širokog određenja javnih politika razvijen je »koordinatni sustav« (slika 1.) koji je korišten kao heurističko sredstvo za mapiranje različitih tipova politika koje su analizirane u projektu.

Slika 1. pokazuje da se politike međusobno razlikuju s obzirom na dvije dimenzije. Prva dimenzija razlikuje politike s obzirom na razinu konkretnosti, od diskursa i koncepata (npr. ekonomija temeljena na znanju) do vrlo konkretnih mjera i programa (npr. dvotjedno osposobljavanje za mlade iz ranjivih društvenih skupina). Druga dimenzija podrazumijeva formalno inicirane i vođene politike (npr. ministarstva) do onih koje su neformalne i koje vode npr. nevladine organizacije. Pri mapiranju i analizi politika cjeloživotnog učenja u zemljama koje su sudjelovale u projektu u obzir su uzimane obje dimenzije (Kotthof i sur., 2017.).

Analiza se temelji na 3 teorijska koncepta:

- kulturna politička ekonomija (eng. cultural political economy) koja objašnjava važnost mobilizacije političkih ideja i percepciju političkih aktera u objašnjenju dinamike i rezultata obrazovnih politika (Jessop, 2010.)

- teorija životnog puta (eng. life course theory) koja povezuje javne politike $\mathrm{s}$ različitim životnim uvjetima, očeki-

Slika 1.

Koordinatni sustav za mapiranje politika cjeloživotnog učenja

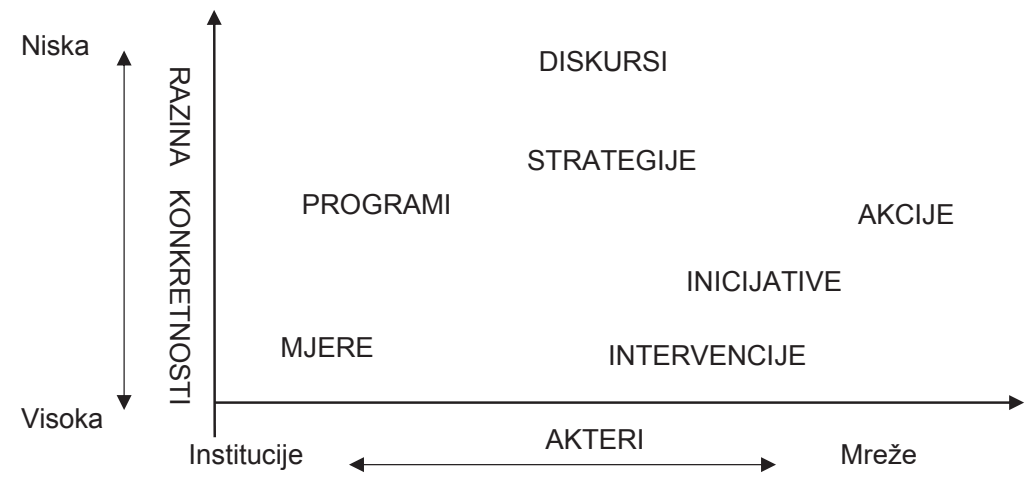

Izvor: prilagođeno prema Kotthof i sur., 2017: 17. 
vanjima i projektima mladih (Walther, 2006.; Nestor, 2015.) te

- upravljanje (eng. government) koje osvjetljava načine na koje javni i privatni subjekti (zajedno ili pojedinačno) doprinose zajedničkom dobru i rješavanju zajedničkih izazova politika cjeloživotnog učenja (Field, 2000.; Kemp, 2005.; Duit i Galaz, 2008.).

Pristup kulturno-političke ekonomije pomaže tumačenju politika cjeloživotnog učenja s obzirom na njihove orijentacije, ciljeve i konstrukciju ciljnih skupina. Teorija životnog puta omogućava razumijevanje socijalne realnosti mladih i podloga je za analizu individualnih životnih puteva unutar šireg socijalnog okvira (obrazovni sustav, tržište rada i sustav socijalne zaštite). Upravljanje osvjetljava djelovanje aktera javnih politika, njihove međusobne interakcije i načine realizacije kolektivnih odluka, imajući u vidu da je, sukladno novom institucionalizmu, institucionalno djelovanje u mnogome uvjetovano vrijednostima, pravilima, poticajima i modelom interakcija među pojedincima u njima (Peters, 2007.).

U ovom se radu analiziraju međusobne povezanosti i koordinacije djelovanja različitih relevantnih aktera i sektora koji su uključeni u definiranje javnih politika koje (među ostalim) adresiraju cjeloživotno učenje mladih.

\section{METODA}

\section{Izvori podataka}

U projektu je sudjelovalo devet država članica Europske unije - Austrija, Bugarska, Hrvatska, Finska, Njemačka, Italija, Portugal, Španjolska i Velika Britanija. Države uključene u projekt razlikuju se s obzirom na strukturu tržišta rada, odgojno-obrazovni sustav, sustav socijalne zaštite te stilove razvoja i donošenja javnih politika. U svakoj su zemlji analizirane dvije tzv. funkcionalne regije, pa je ukupno analizirano 18 funkcionalnih regija (slika 2.). Radi se o geografskom području u kojem se razvijaju određene vrste gospodarske aktivnosti, a funkcionalni odnosi među institucijama i stanovništvom su maksimizirani, uz istodobnu minimizaciju ovisnosti o drugim regijama i/ili zajednicama. Prema tome, funkcionalna regija zadovoljava kriterij unutarnje kohezivnosti i razmjerne neovisnosti o drugim prostornim cjelinama i interakcijama izvan regije (Klapka, Halás i Tonev, 2013.).

Podaci prikupljeni u navedenim funkcionalnim regijama u ovom su radu tretirani na razini zemalja uključenih u projekt. Istraživači su u svakoj funkcionalnoj regiji identificirali i analizirali najvažnije javne politike iz sektora obrazovanja, zapošljavanja i socijalne zaštite mladih koje adresiraju cjeloživotno učenje. Kao orijentacija pri odabiru politika korištene su tri ranije navedene teorijske perspektive i ranije definirana istraživačka pitanja. Nakon identifikacije politika, one su analizirane u odnosu na specifične kontekste. Ukupno su analizirane 134 javne politike (tablica 1.). Kriteriji za odabir i analizu javnih politika bili su:

- sektor (tržište rada, obrazovanje, socijalne politike za mlade i međuresorne politike)

- ciljevi/problemi koje javne politike adresiraju (npr. nezaposlenost mladih, NEET, socijalna isključenost, mladi koji rano napuštaju obrazovanje)

- ciljna skupina (npr. dob, spol, migrantski status)

- prijedlozi rješenja problema

- kriteriji uspješnosti

- vremenski okvir rješavanja problema (npr. kratkoročni, srednjoročni, dugoročni)

- način upravljanja i provođenja (npr. državna razina, lokalna razina)

- način financiranja (npr. država, korporacije). 
Slika 2.

Funkcionalne regije uYOUNG_ADULLLT projektu

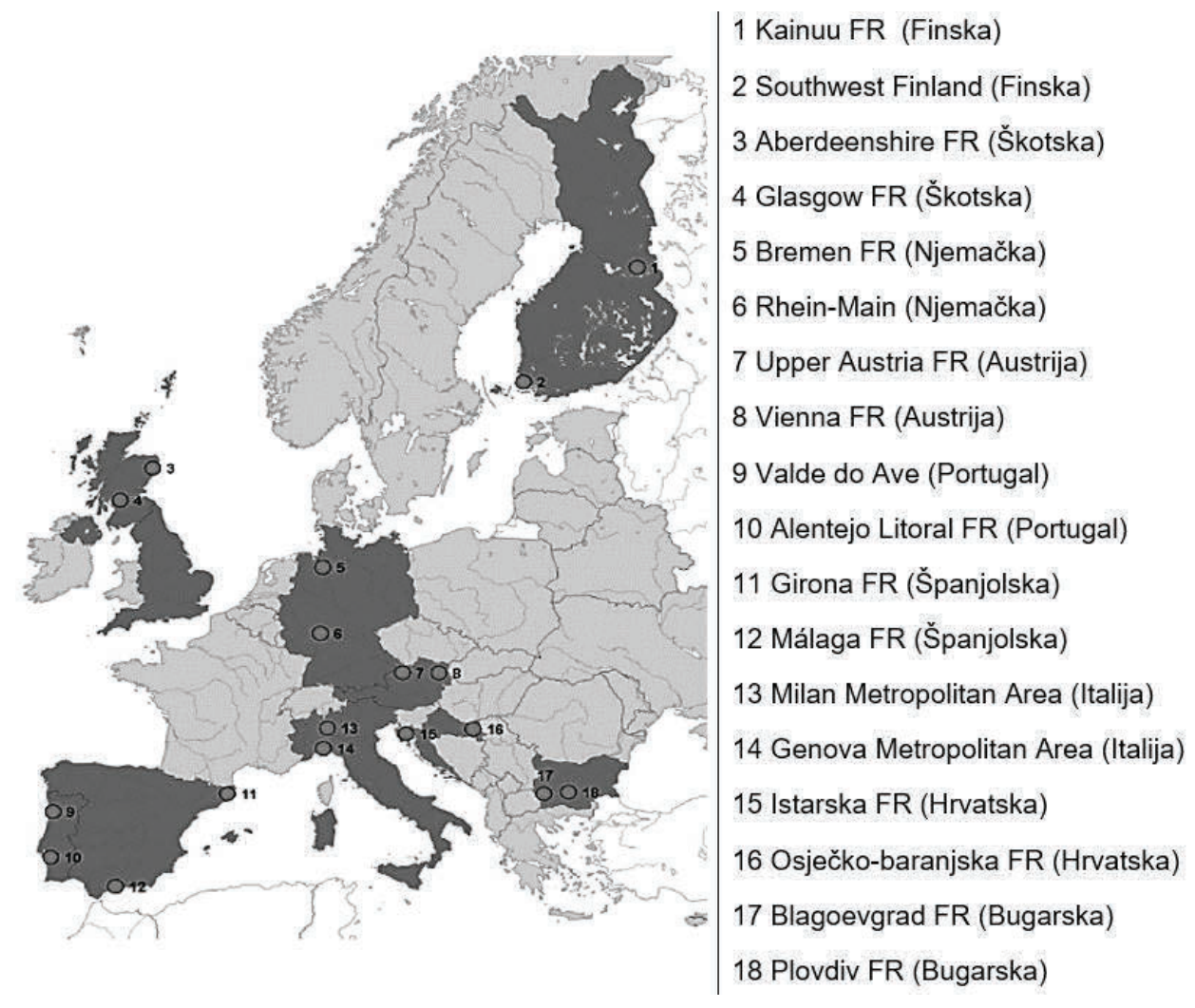

Tablica 1.

Struktura uzorka analize ${ }^{5}$

\begin{tabular}{lccccc}
\hline \multicolumn{1}{c}{ Država } & Tržište rada & Obrazovanje & $\begin{array}{c}\text { Socijalne politike za } \\
\text { mlade }\end{array}$ & $\begin{array}{c}\text { Međuresorne } \\
\text { politike }\end{array}$ & Ukupno \\
\hline Austrija & 6 & 1 & 1 & 4 & 12 \\
\hline Bugarska & 1 & 1 & 0 & 4 & 6 \\
\hline Hrvatska & 10 & 7 & 4 & 0 & 21 \\
\hline Finska & 13 & 13 & 14 & 1 & 41 \\
\hline Italija & 3 & 3 & 7 & 3 & 16 \\
\hline Njemačka & 2 & 6 & 6 & 4 & 18 \\
\hline Portugal & 0 & 2 & 1 & 4 & 7 \\
\hline Španjolska & 3 & 2 & 1 & 0 & 6 \\
\hline Škotska (UK) & 3 & 1 & 2 & 1 & 7 \\
\hline Ukupno & 41 & 36 & 36 & 21 & 134 \\
\hline
\end{tabular}

${ }_{5}$ Točan opis analiziranih LLL politika dostupan je u: Kotthof, H i sur. (2017). International Report: LLL policies and Inclusion in Education and Work. YOUNG_ADULLLT Working Paper. Freiburg: University of Education Freiburg. 
Među analiziranim javnim politikama, $30,59 \%$ pripada politikama koje se odnose na tržište rada, $26,86 \%$ obrazovnim politikama, 26,86\% socijalnim politikama za mlade, dok je $15,67 \%$ politika međuresornog karaktera, što znači da su pozicionirane u dva ili tri područja. Analizirane politike odnose se na mlade odrasle (eng. young adults), odnosno na mlade osobe u dobi od 18 do 29 godina, a razvijene su u razdoblju od 2010. do 2016. godine ${ }^{6}$.

\section{Obrada i kodiranje podataka}

Za obradu podataka korištena je metoda analize dokumenata. Analiza dokumenata je istraživačka metoda kvalitativne paradigme koja podrazumijeva da istraživači interpretiraju odabrane dokumente te im daju značenje u odnosu na ciljeve njihovog istraživanja (Bowen, 2009.). Radi ilustracije obilježja javnih politika, koriste se intervjui s njihovim provoditeljima.

Sve podatke prikupljene tijekom projekta prvo su analizirali i interpretirali istraživači u zemljama sudionicama, a potom su rezultati dobiveni na nacionalnoj razini uključeni u analizu na međunarodnoj razini i prikazani u obliku međunarodnih izvještaja. Za potrebe ovog rada izdvojeni su podaci koji odgovaraju na istraživačka pitanja. Oni su grupirani u 3 cjeline s pripadajućim kodovima. To su:

- mehanizmi formuliranja i implementacije javnih politika (decentralizirani, centralizirani i mješoviti)

- dominantni ciljevi javnih politika (ekonomski, socijalni, obrazovni i ekonomski ili obrazovni i socijalni)

- razine i mehanizmi koordinacije javnih politika (centralno upravljani lokalizam, laissez faire lokalizam, demokratski lokalizam i tradicionalna hijerarhijska država).
Pojam (de)centralizacije odnosi se na mjesto/poziciju formalne ovlasti i moći pri donošenju politika cjeloživotnog učenja. U tom smislu, centralizacija znači donošenje odluka i formuliranje politika u središtu, a decentralizacija znači prijenos ovlasti iz središta prema periferiji (Karlsen, 2000.). U mješovitim mehanizmima formuliranja politika postoji podjela odgovornosti između središnjih i lokalnih (regionalnih) nositelja vlasti i donositelja odluka. Uobičajena objašnjenja za koordinaciju nekog procesa su uključivanje različitih ljudi u zajedničko djelovanje radi postizanja nekog cilja ili koristi (Saxena, 2009.), prilagođavanje različitih elemenata u integrirano i skladno djelovanje (Ben-Gera, 2009.) ili način upravljanja međusobno povezanih aktivnosti iz različitih sektora (Král, 2007.). Proces koordinacije odnosi se na organizaciju i usklađivanje različitih procesa i aktivnosti koji se odvijaju istovremeno ili uzastopno. Prema Hogl (2002.), sektori su koordinirani kada njihove politike i programi pokazuju minimalnu redundantnost (dvije inicijative usmjerene istom cilju koje ne uzimaju u obzir jedna drugu), minimalnu neusklađenost (različiti ciljevi i zahtjevi međusobno usporedivih politika) i najmanje neriješenih pitanja i propusta (eng. policy gaps). Slično tvrdi i Peters (1998., 2006.), koji definira koordinaciju kao krajnje stanje u kojima politike i programe vlade karakteriziraju minimalna suvišnost osoblja, minimalna neusklađenost i minimalno postojanje međuprostora. Integrirani pristup različitim politikama trebao bi se sastojati od nekoliko vrsta koordinacije. To su vertikalna koordinacija između različitih razina na kojima se politike donose (međunarodna, nacionalna, regionalna, lokalna), horizontalna koordinacija između različitih područja politike (sadržajnih sektora) i koordinacija između različitih nositelja interesa iz javnog, privatnog i nevladinog sektora. Problemi prilikom

\footnotetext{
${ }^{6}$ Razdoblje je uvjetovano dinamikom provedbe projekta i potrebom vremenskog definiranja jedinica analize.
} 
koordinacije, prema Petersu (1998.), nastaju zbog različitih interesa sudionika uključenih u implementaciju javnih politika, bilo da su njihovi interesi različiti zbog razlika u političkim preferencijama ili jednostavno zbog birokratskih »trkališta«. Uobičajena koordinacija javnih politika događa se na način »odozgo nadolje«, gdje je hijerarhija dana onima u centralnim agencijama (Davis, 1995.). Međutim, Peters (1998.) diskutira kako se na koordinaciju ne treba gledati kao na dihotomiju, već kao na kontinuum.

Dok je obrazovna dimenzija cjeloživotnog učenja fokusirana na stjecanje znanja i razvoj kompetencija osobe, ekonomska dimenzija prepoznatljiva je u ciljevima koji su usmjereni povećanju mogućnosti osoba da se uključe i sudjeluju u tržištu rada. Ti su ciljevi prepoznatljivi u investiranju u obrazovanje, olakšavanju zapošljavanja mladih, povezivanju tržišta rada i obrazovanja i sl. Socijalnu dimenziju cjeloživotnog učenja karakteriziraju ciljevi koji se dominantno odnose na smanjivanje nejednakosti pristupa tržištu rada mladima u ranjivim situacijama (teško zapošljivi mladi, migranti, mladi koji su prerano napustili školovanje i drugi). Ukratko, pretežno obrazovna dimenzija ciljeva cjeloživotnog učenja vidljiva je u omogućavanju učenja neovisno o kontekstu i dobi korisnika, ekonomska dimenzija u usmjerenosti obrazovanja na olakšavanje zapošljavanja, a socijalna dimenzija u osiguravanju dostupnosti obrazovanja i zapošljavanja mladima u ranjivim situacijama (Gass, 1996.).

$\mathrm{S}$ obzirom na razine i mehanizme koordinacije, glavno je pitanje potiču li decentralizirani procesi veću suradnju i demokratsko donošenje odluka i politika na lokalnoj i regionalnoj razini, ili pak osiguravaju manju intervenciju države koja tada ostavlja više prostora za privatizaciju, učinkovitost tržišta, deregulaciju i isključivanje. Spomenuta tenzija između odnosa stupnja centralizacije te javnog i privatnog sektora potaknula je razvoj četiri modela lokalizama (Capsada-Munsech i sur., 2018.):

- Centralizirano upravljani lokalizam predstavlja kombinaciju središnjeg mehanizma usmjeravanja i kontroliranja (preko nacionalnih institucija) i centralno osmišljenih elemenata utjecaja politike, kao što su ciljevi, mjere uspješnosti, financiranje, načini nadziranja i nacionalne inicijative, unutar kojih se ujedno potiče konkurencija između pružatelja usluga na kvazi-tržište.

- Laissez faire lokalizam odnosi se na smanjenje uloge središnje državne vlasti. Naglasak je na institucionalnoj autonomiji, poticanju privatizacije $\mathrm{u}$ kompetitivnom okruženju, djelovanju u minimalno birokratiziranim uvjetima, osnaživanju građana i zajednica kao konzumenata $\mathrm{i}$ aktivnih sudionika $\mathrm{u}$ javnim uslugama i promicanju »lokalnih tržišta« (npr. zdravlja, obrazovanja).

- Demokratski lokalizam promiče ravnotežu ovlasti i odnosa između demokratski izabranih nacionalnih, regionalnih i lokalnih vlasti, te također naglašava sudjelovanje javnosti u kreiranju i ponudi usluga, promicanje ideja javnog dobra, uvažavanje »odozdo prema gore « informacija u kreiranju politika, te snažnu uključenost svih socijalnih partnera u kreiranje politika.

- Tradicionalna hijerarhijska država odnosi se na centralizirane države u kojima ne postoji niti jedan od prethodnih uvjeta decentralizacije.

\section{REZULTATI}

\section{Mehanizmi formuliranja i implementacije politika cjeloživotnog učenja}

Uspješna koordinacija zahtijeva jaku suradnju između pružatelja usluga za razvoj 
vještina/kompetencija i njihovih korisnika. Centraliziran pristup određivanju prioriteta javnih politika može umanjiti mogućnost planiranja programa koji su relevantni za sadržaj obrazovnih programa i tržište rada u lokalnom kontekstu (Hodgson i Spours, 2012.).

S druge strane, decentralizacija promovira uravnoteženost ovlasti i odnosa između demokratski izabranih i odgovornih nacionalnih, regionalnih i lokalnih vlasti. Također, naglašava sudjelovanje svih dionika u razvoju i implementaciji programa i usluga, promicanje djelovanja za opće dobro, učinkovito prikupljanje i korištenje povratnih informacija prema modelu »odozdo prema gore« i snažnu uključenost svih zainteresiranih socijalnih partnera u kreiranju javnih politika. S obzirom na vertikalnu koordinaciju, decentralizirani modeli koordinacije često su praćeni ambicijom da se sektorske politike ne kreiraju prema načelu »odozgo prema dolje«, to jest da se politike kreiraju prema lokalnim potrebama. Rezultati analize s obzirom na dominantne mehanizme formuliranja i implementacije javnih politika cjeloživotnog učenja u analiziranim europskim državama prikazani su u tablici 2 . guće je donijeti zaključke na razini pojedinih zemalja uključenih u istraživanje. U Bugarskoj, Hrvatskoj, Portugalu i, u manjoj mjeri, Škotskoj, stupanj centralizacije je visok. U Njemačkoj, Finskoj i Italiji politike se uglavnom donose decentralizirano, dok su u Austriji i Španjolskoj prisutni mješoviti mehanizmi formuliranja i implementacije politika cjeloživotnog učenja.

Decentralizirane mehanizme formuliranja i implementacije politika ilustrira sljedeći primjer: »Regionalne vlasti igraju središnju ulogu u definiranju programa za razvoj kvalifikacija/vještina u funkcionalnoj regiji Bremen (...) Postoji visoka razina autonomije na regionalnoj razini-udruge poslodavaca i centri za zapošljavanje definiraju projekte, njihove ciljeve, ciljne skupine i kriterije uspješnosti« (Weiler i sur., 2017.b: 45).

Centralizirani mehanizmi uočljivi su, pak, u primjeru Hrvatske: »Strategije $u \check{c} i$ joj sam izradi participirala su vrlo široke. Prije svega, strategije su razvili konzultanti koji nisu iz Istre. Koliko ja mogu razumjeti, oni imaju točno određeni obrazac prema kojem razvijaju strategije koje su jako široke $i$ ne reflektiraju lokalne potrebe«. (Domović, Bouillet i Pažur, 2018.: 25).

Tablica 2.

Dominantni mehanizmi formuliranja i implementacije politika cjeloživotnog učenja

\begin{tabular}{lccc}
\hline Država & Decentralizirani mehanizmi & Centralizirani mehanizmi & Mješoviti mehanizmi \\
\hline Austrija & & $\mathrm{x}$ & $\mathrm{x}$ \\
\hline Bugarska & & \\
\hline Hrvatska & $\mathrm{x}$ & \\
\hline Finska & $\mathrm{x}$ & $\mathrm{x}$ & \\
\hline Italija & $\mathrm{x}$ & $\mathrm{x}$ \\
\hline Njemačka & & $\mathrm{x}$ \\
\hline Portugal & & & \\
\hline Španjolska & & \\
\hline Škotska (UK) & & \\
\hline
\end{tabular}

Izvor: prilagođeno prema: Capsada-Munsech i sur., 2018.

Uz postojanje određenih varijacija $u$ promatranim funkcionalnim regijama $\mathrm{s}$ obzirom na stupanj (de)centralizacije, mo-
Primjer iz Škotske prikazuje mješoviti mehanizam formuliranja i implementacije politika: »Stoga se može tvrditi da, čak $i$ 
ako je smjer politike škotske vlade uvelike propisan (centralizacija), ona je dovoljno fleksibilna $i$ dovoljno široka da omogući kontekstualnu provedbu te donošenje aktivnosti $i$ obrazovnih programa od strane regionalnih i lokalnih aktera." (Capsada-Munsech i Valiente, 2017.: 22).

Prilikom interpretacije prikazanih podataka treba imati na umu da autonomija na regionalnim razinama uvelike ovisi o postojanju i snazi federalnih struktura unutar pojedinih država. U državama s jakim federalnim strukturama kao što su Škotska, Austrija (slab federalizam po ustavu, ali prilično jak federalizam u praksi) ili Njemačka, odabrane funkcionalne regije su autonomnije i provedba politika cjeloživotnog učenja na regionalnoj razini se djelomično razlikuje od onih na nacionalnoj razini. S druge strane, u Portugalu, Hrvatskoj ili Bugarskoj teško je pronaći strogo regionalne politike cjeloživotnog učenja.

\section{Dominantni ciljevi politika cjeloživotnog učenja}

U proteklim se godinama cjeloživotno učenje od početne ideje razvilo u dominantno načelo i orijentaciju razvoja brojnih nacionalnih obrazovnih sustava. Njegova važnost ističe se u nizu međunarodnih akcijskih planova, deklaracija, dokumenata i konferencija (Jukić i Ringel, 2013.).

U 90-im godinama 20. stoljeća u Europi se afirmira cjeloživotno učenje kao politika koja odgovara na probleme ekonomske krize i povećane nezaposlenosti (Žiljak, 2005.). Tada se pomiče fokus s obrazovanja, koje je institucionalizirani i organizirani proces, na cjeloživotno učenje koje uključuje sve oblike učenja u svim životnim okolnostima. Kako se ti trendovi odražavaju na politike cjeloživotnog učenja u državama uključenima u ovu analizu, prikazano je u tablici 3 .
Tablica 3.

Dominantni ciljevi politika cjeloživotnog učenja

\begin{tabular}{lccc}
\hline Država & $\begin{array}{c}\text { Obrazovni Ekonomski } \\
\text { ciljevi }\end{array}$ & $\begin{array}{c}\text { Socijalni } \\
\text { ciljevi }\end{array}$ & ciljevi \\
\hline Austrija & $\mathrm{x}$ & $\mathrm{x}$ & \\
\hline Bugarska & $\mathrm{x}$ & $\mathrm{x}$ & \\
\hline Hrvatska & $\mathrm{x}$ & $\mathrm{x}$ & \\
\hline Finska & $\mathrm{x}$ & & $\mathrm{x}$ \\
\hline Italija & & $\mathrm{x}$ & $\mathrm{x}$ \\
\hline Njemačka & $\mathrm{x}$ & & $\mathrm{x}$ \\
\hline Portugal & & $\mathrm{x}$ & $\mathrm{x}$ \\
\hline Španjolska & & $\mathrm{x}$ & $\mathrm{x}$ \\
\hline Škotska (UK) & $\mathrm{x}$ & & $\mathrm{x}$ \\
\hline
\end{tabular}

Izvor: prilagođeno prema: Rambla i sur., 2018.

Dominacija obrazovnih ciljeva javnih politika oslikava sljedeći komentar eksperta: »Projekti omogućuju mladima pristup obrazovanju, da uđu u obrazovni sustav, da unaprijede svoje kompetencije." (Bouillet, Pažur i Domović, 2017.: 18), a ekonomski ciljevi vidljivi su u izjavi: »Odmakli smo se od koncepta u kojem samo smještamo mlade ljude u uobičajene programe. Jako daleko od teorije, jer samo ih uključiti u standardni program uopće ne funkcionira. Ali, funkcionira uključiti mlade direktno u posao.« (Pot, Alexander i Cefalo, 2017.: 45). Naposljetku, primjer socijalnih ciljeva vidljiv je u sljedećoj izjavi: »Ljudi u Kainuиu su sramežljivi i skromni, opremljeni nekom vrstom niskog samopoštovanja, tako da trebaju neku vrstu ohrabrenja, poznavanja vlastitog znanja $i$ vještina, trebaju da im ponudite poslodavce (...) navikli su na to da ne trebaju isticati što mogu, ne trebaju se hvaliti, trebaju biti skromni $i$ čekati (...), ali poslodavci to ne žele, oni ne dolaze i ne odvode nas od kuće ... (Risto i sur., 2017.: 21).

Analiza devet nacionalnih izvješća pokazuje da su politike koje se odnose na cjeloživotno učenje uglavnom usredotočene na doprinos gospodarskom rastu i na održavanje i povećanje razine međunarodne konkurentnosti, vrlo često naglašavajući 
utilitarističku svrhu obrazovanja (utilitaristički humanizam). Naravno, postoje i politike cjeloživotnog učenja koje se bave obrazovanjem unutar šireg koncepta emancipacijskog humanizma i koje pokušavaju konceptualizirati obrazovanje kao cilj sam po sebi, ali te su politike manje zastupljene (Finska predstavlja značajnu iznimku u tom pogledu). Ova situacija nije iznenađujuća, već ju je moguće interpretirati kao rezultat političkih programa međunarodnih aktera (npr. Europska komisija, OECD, Svjetska trgovinska organizacija, itd.) koji su tijekom 1990-ih razvili politike i dokumente temeljene na pristupu utilitarističkog humanizma (Kotthof, 2017.).

Politike cjeloživotnog učenja generalno, kao i one koje se odnose samo na mlade, u mnogim su zemljama u početku primjene bile usmjerene na osobni razvoj ljudi i njihovo cjeloživotno učenje prema načelu jednakih mogućnosti i ideji demokratizacije obrazovanja. Međutim, u novije vrijeme one su više usredotočene na utilitarističku viziju (Bugarska, Italija, Finska, Njemačka i Škotska), temelje se na neoliberalnoj ideologiji i uglavnom su usmjerene na zapošljavanje, razvoj radnih kapaciteta i konkurentnost radne snage.

\section{Razine i mehanizmi koordinacije politika cjeloživotnog učenja}

Nema sumnje da postoji potreba za suradnjom između obrazovnih institucija, poslodavaca i predstavnika vlasti. Rezultat te suradnje treba biti prilagođavanje obrazovnog sustava potrebama tržišta rada. Drugim riječima, obrazovanje treba omogućiti stjecanje vještina koje mladima po završetku školovanja omogućavaju zapošljavanje. Poslodavci trebaju biti uključeni u proces obrazovanja i formiranja vještina, odnosno obrazovne institucije trebaju prilagoditi svoje programe modernoj proizvodnji i brzim tehnološkim promjenama. Suradnja u procesu razvoja kurikuluma i kontakti poslo- davaca s mladima preduvjet su za uspješno stažiranje, poboljšavanje zapošljivosti mladih i jednostavniju tranziciju mladih iz obrazovanja u svijet rada. Suradnja između škola i poslodavaca može potaknuti i druge oblike suradnje u zajednici, što može povoljno djelovati na lokalni gospodarski razvoj, koji povratno može stvoriti nova radna mjesta za mlade. Razine i mehanizmi koordinacije u politikama cjeloživotnog učenja u analiziranim europskim državama prikazani su u tablici 4.

Tablica 4.

Razine i mehanizmi koordinacije politika cjeloživotnog učenja

\begin{tabular}{lccc}
\hline Država & $\begin{array}{c}\text { Centralno } \\
\text { upravljani } \\
\text { lokalizam }\end{array}$ & $\begin{array}{c}\text { Laissez } \\
\text { faire } \\
\text { lokalizam }\end{array}$ & $\begin{array}{c}\text { Demokratski } \\
\text { lokalizam }\end{array}$ \\
\hline Austrija & $\mathrm{x}$ & & $\mathrm{x}$ \\
\hline Bugarska & $\mathrm{x}$ & & \\
\hline Hrvatska & $\mathrm{x}$ & & $\mathrm{x}$ \\
\hline Finska & & $\mathrm{x}$ & $\mathrm{x}$ \\
\hline Italija & & $\mathrm{x}$ & $\mathrm{x}$ \\
\hline Njemačka & & & \\
\hline Portugal & $\mathrm{x}$ & & $\mathrm{x}$ \\
\hline Španjolska & $\mathrm{x}$ & & $\mathrm{x}$ \\
\hline Škotska (UK) & $\mathrm{x}$ & &
\end{tabular}

Izvor: prilagođeno prema Capsada-Munsech i sur., 2018.

Dok je Bugarsku, Hrvatsku i Portugal razmjerno jednostavno svrstati u centralno upravljani lokalizam, Austriju, Škotsku i Španjolsku karakterizira mješavina dvaju modela (centralno upravljanog lokalizma i demokratskog lokalizma). Dominacija jednog modela nije prepoznatljiva ni u Finskoj i Italiji, gdje su prepoznati elementi laissez. faire i demokratskog lokalizma. Demokratski lokalizam u većoj mjeri prepoznatljiv je samo u Njemačkoj. Elementi tradicionalno hijerarhijske države nisu prisutni ni u jednoj od devet analiziranih država.

Centralno upravljani lokalizam oslikava sljedeći primjer: »Odnosi između regi- 
onalnih i nacionalnih institucija mogu se prvenstveno prepoznati u ulozi nositelja lokalnih vlasti koji su odgovorni za primjenu nacionalnih obrazovnih politika u lokalnim sredinama...« (Dzhabarova i sur., 2017.: 18). S druge strane, laisez faire lokalizam karakteriziraju odnosi opisani u Weiler i sur. (2017.b: 6-7): »Postoji gusta mreža suradnje između aktera odgovornih za razvoj vještina u funkcionalnoj regiji Rhein-Main. Suradnja se često organizira s obzirom na potrebe tržišta rada (npr. ugovorni odnos između javnih institucija i neovisnih pružatelja usluga kako bi se osigurao razvoj specifičnih vještina) $i$ može se odvijati prema različitim modelima.« Demokratičnost proizlazi iz prakse opisane u (Risto i sur., 2017.: 18): »Kainuu je jako mala regija, tako da je suradnja dobra zbog toga što se mnogi dionici međusobno poznaju, dugo zajedno rade $i$ surađuju $i$ u stalnom su dijalogu. Nema ograničenja i granica, $i$ zato, to što smo mali u ovom slučaju znači agilnost, fleksibilnost $i$ dobru suradnju.«

\section{ZAKLJUČNA RAZMATRANJA}

Cilj ove analize odnosi se na utvrđivanje načina na koji je cjeloživotno učenje operacionalizirano i implementirano u javnim politikama u sustavima obrazovanja, zapošljavanja i socijalne zaštite mladih. Pokazalo se da se devet europskih država međusobno razlikuje u svim analiziranim obilježjima. Drugim riječima, u različitim kontekstima javne se politike mogu različito interpretirati s obzirom na mehanizme njihova formuliranja i implementacije, dominantne ciljeve koje postavljaju, međusobnu kompatibilnost i koordinaciju politika cjeloživotnog učenja iz triju različitih područja (tržišta rada, obrazovanja i socijalne zaštite).

Vidljivo je da je u većini zemalja sve slabije prisutan humanistički fokus na osobni razvoj pojedinca u korist sve jače prisutnosti instrumentalnog i utilitarnog pristupa koji naglašava ekonomski rast $\mathrm{i}$ individualnu zapošljivost. Drugim riječima, cjeloživotno učenje sve se manje razumije kao osobno dobro, a sve više kao »investicija u ekonomski razvoj« (Biesta, 2006.: 169). Javne politike u odnosu na cjeloživotno učenje teže tome da budu implementirane kao niz poredanih, normaliziranih koraka, koji se trebaju slijediti kako bi se ostvarila društvena očekivanja postizanja »normalnog « životnog tijeka. Odnosno, njihova je uloga da budu instrumenti u procesu ponovne standardizacije životnog tijeka koji se shvaća kao obrazovanje - posao - mirovina.

Pokazalo se da u Austriji prevladavaju mješoviti mehanizmi formuliranja i implementacije javnih politika s pretežno obrazovnim i socijalnim ciljevima koji se postižu uz primjenu centralno upravljanog i demokratskog lokalizma. Mješovite mehanizme formuliranja javnih politika te primjenu centralno upravljanog i demokratskog lokalizma nalazimo i u Španjolskoj, gdje prevladavaju ekonomski i socijalni ciljevi cjeloživotnog učenja. Bugarsku karakterizira centralizirani mehanizam formuliranja, implementacije i upravljanja javnim politikama, a njihovi ciljevi su pretežno obrazovni i ekonomski. Ista obilježja prepoznaju se i u Hrvatskoj. Centralizirani mehanizmi formuliranja politika te usmjerenost prema obrazovnim i socijalnim ciljevima vidljivi su u Škotskoj, u kojoj su jednako zastupljeni centralno upravljani i demokratski lokalizam. Centralizirani mehanizmi formuliranja, implementacije i upravljanja javnim politikama dominiraju i u Portugalu, a ciljevi su pretežno ekonomski i socijalni. U Finskoj se prepoznaju decentralizirani mehanizmi formuliranja i implementacije javnih politika, usmjerenost prema obrazovnim i ekonomskim ciljevima te laissez faire i demokratski lokalizam. Ova su obilježja prisutna i u Njemačkoj, a razlika je u prevladavajućem demokratskom lokalizmu. U Italiji također prevladavaju decentralizirani mehanizmi formuliranja i implementacije 
politika, ali su izraženiji ekonomski i socijalni ciljevi javnih politika.

Rezultati analize posredno upućuju na zaključak da najveće razlike u formuliranju i implementaciji politika iz tri različita sektora proizlaze iz dominantnog modela njihove koordinacije. Naime, javne politike usmjerene razvoju cjeloživotnog učenja uglavnom se donose na europskoj razini i istraživanja pokazuju da one nailaze na probleme prilikom implementacije na nacionalnu i/ili regionalnu razinu (Kotthoff i sur., 2007), upravo zato što podrazumijevaju internacionalnu koordinaciju (Peters, 1998.). S time u vezi, Peters (2005.) razlikuje četiri razine koordinacije. Najnižu razinu koordinacije naziva »negativnom koordinacijom« te nju karakterizira kao onu koja podrazumijeva da različite politike i programi »zaobilaze jedni druge« i podrazumijevaju minimalni politički kapital. Druga razina se naziva "pozitivna koordinacija « te nadilazi puko prepoznavanje između različitih programa i politika. Pri tome različite institucije nastoje surađivati kako bi pružale bolje usluge svojim korisnicima. Ova razina koordinacije podrazumijeva da individualne organizacije i dalje ostaju uvelike autonomne i slijede vlastite individualne ciljeve. Treća razina koordinacije je »integracija politika«, koja uključuje koordinaciju ciljeva različitih organizacija i institucija. Ova razina koordinacije je izazovna jer podrazumijeva da se koordinacija ne odvija samo na razini implementacije politika i programa, već i na razini političkih ciljeva raznih organizacija. Najviša razina koordinacije su »strategije za vlade«. One podrazumijevaju da postoji jasna vizija za budućnost o razvoju politike i vlade. Problemi koji se javljaju prilikom zadnje dvije razine koordinacije su upravo problemi koji se često javljaju u području politika koje se tiču cjeloživotnog učenja. Internacionalna koordinacija (koja se nužno odvija na trećoj i četvrtoj razini koordinacije), prema istom autoru, jedan je od suvremenih izazova u procesu koordinacije javnih politika, s obzirom da takav oblik koordinacije očekuje od vlade višu razinu političkih odabira (usuglašavanje oko političkih ciljeva i strategija) i veću razinu diskusije i suradnje između svih uključenih aktera.

\section{LITERATURA}

Babić Krešić, I. (2014). Javne politike u procesu globalizacije i europeizacije i politika zapošljavanja. Nova prisutnost, 12(3), 413-430. https://hrcak. srce.hr/130023

Ben-Gera, M. (2009). Coordination at the center of government for better policy making. Support for Improvement in Governance and Management (SIGMA). A joint initiative of the OECD and the European Union, Conference on Public Administration Reform and European Integration, p. 2.

Biesta, G. (2006). What's the point of lifelong learning if lifelong learning has no point? On the democratic deficit of policies for lifelong learning. European Educational Research Journal, 5(3-4), 169-180. https://doi.org/10.2304/ eerj.2006.5.3.169

Bouillet, D., Pažur, M., \& Domović, V. (2017). Qualitative analysis: Croatian National Report. Zagreb: University of Zagreb.

Bowen, G. A. (2009). Document analysis as a qualitative research method. Qualitative Research Journal, 9(2), 27-40. https://doi.org/10.3316/ QRJ0902027

Busemeyer, M. R., \& Trampusch, C. (2012). The comparative political economy of collective skill formation. In M. R. Busemeyer \& C. Trampusch (Eds.), The Political Economy of Collective Skill Formation (pp. 1-44). Oxford: Oxford University Press.

Capsada-Munsech, Q., \& Valiente, O. (2017). WP6 Comparative Analysis Skills Supply and Demand. National Report Scotland. Glasgow: University of Glasgow.

Capsada-Munsech, Q., Valiente, O., Palumbo, M., Cossetta, A., Pandolfini, V., Bouillet, D., \& Ganter de Otero, J. P. (2018). WP6 International Report: Comparative Analysis Skills Supply and Demand.YOUNG_ADULLLT Working Paper. Glasgow: University of Glasgow.

Colebatch, H. K. (2006). What work makes policy?. Policy Sciences, 39(4), 309-321. https://doi. org/10.1007/s11077-006-9025-4 
Colebatch, H. K., \& Hoppe, R. (Eds.) (2018). Handbook on policy, process and governing. Cheltenham: Edward Elgar Publishing.

Davis, G. (1995). A government of routines: Executive coordination in an Australian state. Melbourne: Macmillan Education.

Domović, V., Bouillet, D., \& Pažur, M. (2018). Comparative analysis skills supply and demand. National Croatia. Zagreb: University of Zagreb.

Duit, A., \& Galaz, V. (2008). Governance and complexity - Emerging issues for governance theory. Governance: An International Journal of Policy, Administration, and Institutions, 21(3), 311-335. https://doi.org/10.1111/j.1468-0491.2008.00402.x

Duke, C., \& Hinzen, H. (2011). Adult education and lifelong learning within UNESCO: CONFINTEA, Education for all, and beyond. Adult Learning, 22(4), 18-23. https://doi. org/10.1177/104515951102200404

Dzhabarova, Y., Milenkova, V., Petko, M., \& Apostolov, G. (2017). Comparative Analysis Skills Supply and Demand. National Report Bulgaria. YOUNG_ADULLLT Working Paper. Plovdiv: Paisii Hilendarski University of Plovdiv.

European Centre for the Development of Vocational Training - CEDEFOP. (2014). Terminology of vocational training policy - A multilingual glossary for an enlarged Europe. Luxembourg: Publications Office of the European Union.

European Parliament, \& Council of Europe. (2006). Action Programme in the Field of Lifelong Learning (2004-2006). Official Journal of the European Union L (327), 45-68.

Europska komisija. (2000). Memorandum o cjeloživotnom učenju. Dostupno na http://www. hzpou.hr/?gid=5\&aid=26

Europska komisija. (2015). Strateški okvir za europsku suradnju u području obrazovanja i osposobljavanja. Dostupno na https://ec.europa.eu/ education/policies/european-policy-cooperation/ et2020-framework_hr

Field, J. (2000). Governing the ungovernable: Why lifelong learning policies promise so much yet deliver so little. Educational Management \& Administration, 28(3), 249-261. https://doi. org/10.1177/0263211X000283002

Gass, R. (1996). The goals, architecture and means of lifelong learning - Background paper issued by the European Commission. Luxembourg: Office for Official Publications of the European Communities.

Hake, B. (1999). Lifelong learning in late modernity: The challenges to society, organizations, and in- dividuals. Adult Education Quarterly, 49(2), 7990. https://doi.org/10.1177/074171369904900201

Hill, M. J. (2005). The public policy process (4th ed.). London: Pearson Education.

Hodgson, A., \& Spours, K. (2012). Three versions of "localism": Implications for upper secondary education and lifelong learning in the UK. Journal of Education Policy, 27(2), 193-210. https://doi. org/10.1080/02680939.2011.587541

Hogl, K. (2002). Background Paper on "Inter-Sectoral Co-ordination”. Contribution to COST-Action E19 National Forest Programmes in the European Context.

Hrvatski Sabor. (2014). Strategija obrazovan$j a$, znanosti $i$ tehnologije. Dostupno na https://narodne-novine.nn.hr/clanci/sluzbeni/2014_10_124_2364.html

Jacovkis, J., Barroso, D., Torres, M., \& Luzón, A. (2017). Comparative Analysis Skills Supply and Demand: National Report Spain. YOUNG_ ADULLLT Working Paper. Barcelona: Autonomous University of Barcelona.

Jessop, B. (2010). Cultural political economy and critical policy studies. Critical Policy Studies, 3(3-4), 336-356. https://doi. org/10.1080/19460171003619741

Jukić, R., \& Ringel, J. (2013). Učenje - put ka budućnosti. Andragoški glasnik, 17(1), 25-34. https://hrcak.srce.hr/104941

Ilišin, V., \& Spajić-Vrkaš, V. (2017). Generacija osujećenih: mladi u Hrvatskoj na početku 21. stoljeća. Zagreb: Institut za društvena istraživanja.

Karlsen, G. E. (2000). Decentralized centralism: Framework for a better understanding of governance in the field of education. Journal of Education Policy, 15(5), 525-538. https://doi. org/10.1080/026809300750001676

Katznelson, N. (2016). Rethinking motivational challenges amongst young adults on the margin. Journal of Youth Studies, 20(5), 622-639. https:// doi.org/10.1080/13676261.2016.1254168

Kemp, R., Parto, S., \& Gibson, R. B. (2005). Governance for sustainable development: Moving from theory to practice. International Journal of Sustainable Development, 8(1-2), 12-30. https://doi. org/10.1504/IJSD.2005.007372

Klapka, P., Halás, M., \& Tonev, P. (2013). Functional regions: Concept and types. In XVI. mezinárodní kolokvium o regionálních vědách (pp. 94-101). Available at https://is.muni.cz/do/econ/soubory/ katedry/kres/4884317/41725568/12_2013.pdf

Kotthof, H., Gáfaro, J. F. C., Bittlingmayer, U. H., Boutiuc-Kaiser, A., Parreira do Amaral, M., 
\& Rinne, R. (2017). International Report: LLL policies and inclusion in education and work. YOUNG_ADULLLT Working Paper. Freiburg: University of Education Freiburg.

Král, J. (2007). Introduction to coordination concept. Human Resources Management \& Ergonomics, (2). Available at https://frcatel.fri.uniza.sk/hrme/ files/2007/2007_2_06.pdf

Lee, M., \& Friedrich, T. (2011). Continuously reaffirmed, subtly accommodated, obviously missing and fallaciously critiqued: Ideologies in UNESCO's lifelong learning policy. International Journal of Lifelong Education, 30(2), 151-169. https://doi.org/10.1080/02601370.2010.547619

Mataković, H., \& Cajner Mraović, I. (2014). Stvaranje javnih politika u različitim nacionalnim kontekstima. Pravni vjesnik: časopis za pravne i društvene znanosti Pravnog fakulteta Sveučilišta J.J.Strossmayera u Osijeku,30(3-4), 157-176. https://hrcak.srce.hr/134236

Miošić, N., Berković, J., \& Horvat, M. (2014). Analiza $i$ zagovaranje javnih politika. Zagreb: GONG, Fakultet političkih znanosti.

Nestor, K. R. (2015). Understanding biographicity: Redesigning and reshaping lives in young adulthood [Doctoral dissertation]. Washington, D.C.: Faculty of The Graduate School of Education and Human Development of The George Washington University.

Petek, A. (2012). Što su hrvatske javne politike?. Političke analize, 3(11), 37-45. https://hrcak. srce.hr/142001

Petek, A. (2016). Politološka ekspertiza za javne politike. Suvremene teme, 8(1), 7-23. https://hrcak. srce.hr/174030

Peters, B. G. (1998). Managing horizontal government: The politics of co-ordination. Public Administration, 76(2), 295-311. https://doi. org/10.1111/1467-9299.00102

Peters, B. G. (2005). The search for coordination and coherence in public policy: Return to the center? (Manuscript). University of Pittsburgh.

Peters, B. G. (2007.). Institucionalna teorija u političkoj znanosti: Novi institucionalizam. Zagreb: Fakultet političkih znanosti Sveučilišta u Zagrebu.

Pierre, J., \& Peters, B. G. (2005). Governing complex societies: Trajectories and scenarios. Hampshire: Palgrave MacMillan.

Pot, M., Alexander, L., \& Cefalo, R. (2017). Qualitative analysis. National Report Austria. Vienna: University of Vienna.
Pot, M.,Cefalo, R., \& Kazepov, Y. (2017). Comparative Analysis Skills Supply and Demand. National Report Austria. Vienna: University of Vienna.

Rambla, X., Jacovkis, J., Kovacheva, S., Walther, A., \& Verlage, T. (2018). International Qualitative Analysis Report. YOUNG_ADULLLT Working Paper. Barcelona: Autonomous University of Barcelona.

Risto, R., Järvinen, T., Silvennoinen, H., Tikkanen, J., \& Plamper, R. (2017). Comparative analysis skills supply and demand. National Report Finland.YOUNG_ADULLLT Working Paper. Tur$\mathrm{ku}$ : University of Turku.

Saxena, P. K. (2009). Principles of management: A modern approach. New Delhi: Global India Publication.

Širinić, D. (2016). Priručnik za praćenje javnih politika za organizacije civilnog društva. Osijek: Centar za mir, nenasilje i ljudska prava.

Volles, N. (2016). Lifelong learning in the EU: Changing conceptualizations, actors, and policies. Studies in Higher Education, 41(2), 343-363. https:// doi.org/10.1080/03075079.2014.927852

Vuorinen, R., \& Watts, A.G. (2013). Razvoj politike cjeloživotnog profesionalnog usmjeravanja: Europski priručnik sa smjernicama za oblikovanje politika cjeloživotnog profesionalnog usmjeravanja. Europska mreža politika cjeloživotnog profesionalnog usmjeravanja (ELGPN).

Walther, A. (2006). Regimes of youth transitions. Choice, flexibility and security in young people's experiences across different European contexts. Young, 14(2), 119-139. https://doi. org/10.1177/1103308806062737

Weiler, A., Ganter de Otero, J. P., Parreira do Amaral, M., Boutiuc-Kaiser, A., Schaufler, S., \& Verlage, T. (2017). Comparative analysis skills supply and demand. National Report Germany. YOUNG_ADULLLT Working Paper. Münster: University of Münster.

Weiler, A., Schaufler, S., Parreira do Amaral, M., Ganter de Otero, J. P., Wutzkowsky, F., Valiente, O., Neves, T., \& Ribeiro, A. B. (2017). Launching and research design. State of the Art Report. YOUNG_ADULLLT Working Paper. Münster: University of Münster.

Žiljak, T. (2005). Politike cjeloživotnog učenja u Europskoj uniji i Hrvatskoj. Političko obrazovanje, $1(1), 67-95$. 


\title{
Summary
}

\section{LIFELONG LEARNING OF YOUNG ADULTS IN THE CONTEXT OF PUBLIC POLICIES - A EUROPEAN PERSPECTIVE}

\author{
Dejana Bouillet, Vlatka Domović, Monika Pažur \\ Faculty of Teacher Education, University of Zagreb, \\ Zagreb, Croatia
}

The paper analyses 134 policies which address lifelong learning policies (LLL policies) in nine countries involved in the project Policies Supporting Young Adults in their Life Course: A Comparative Perspective of Lifelong Learning and Inclusion in Education and Work in Europe (YOUNG_ADULLLT, HORIZON 2020). The analysis is based on three theoretical concepts - cultural political economy, life course theory and governance. The objective of the analysis is to determine the ways in which the LLL policies for youth are formulated and implemented in educational, economic and social sectors. The analysis shows the differences between the countries with regard to the stated goals that are a result of different social and economic circumstances. Policy formulation policies range from centralized to decentralized. The objectives of policies are threefold-educational, economic and social, with their representation varying from country to country. The levels and mechanisms of lifelong learning coordination also show the differences between countries with regard to centrally managed localism, laissez faire and democratic localism.

Key words: policy, lifelong learning, young adults, Europe. 